\title{
Effect of micronized zeolite addition to lamb concentrate feeds on growth performance and some blood chemistry and metabolites
}

\author{
N.N. Toprak ${ }^{1 \#}$, A. Yılmaz ${ }^{1}$, E. Öztürk ${ }^{2}$, O. Yigit $^{2}$ \& F. Cedden ${ }^{1}$ \\ ${ }^{1}$ Ankara University, Agriculture Faculty, Department of Animal Science, Ankara, Turkey \\ ${ }^{2}$ Ankara University, Agriculture Faculty, Research and Training Farm, Ankara, Turkey
}

(Received 16 March 2016; Accepted 31 July 2016; First published online 21 September 2016)

\begin{abstract}
Copyright resides with the authors in terms of the Creative Commons Attribution 2.5 South African Licence.
See: http://creativecommons.org/licenses/by/2.5/za

Condition of use: The user may copy, distribute, transmit and adapt the work, but must recognise the authors and the South African Journal of Animal Science.
\end{abstract}

\begin{abstract}
This study was conducted to determine the effects of the addition of micronized zeolite (MZ) on the fattening performance, blood parameters, faecal ash and nitrogen levels of lambs fed concentrate feeds intensively. For two months 25 four-month-old Merino $x$ lle de France crossbred male lambs $(21.1 \pm 1.32 \mathrm{~kg}$ live weight) were fed $100 \mathrm{~g}$ alfalfa hay and a mixed concentrate diet containing $0 \%, 1 \%, 2 \%$ or $3 \%$ additional MZ. At the end of the study, bodyweight gain and feed consumption were not affected by the treatments. Similarly, the addition of up to $2 \% \mathrm{MZ}$ to the diet did not affect slaughter weight, hot carcass or cold carcass weights, but they decreased at $3 \% \mathrm{MZ}$ inclusion. No differences were observed between the groups in terms of blood urea nitrogen, plasma glucose, serum creatinine, triglyceride, sodium, potassium and chlorine concentration. However, serum total protein, calcium and phosphorus concentrations were affected by MZ supplementation. The addition of $M Z$ to the ration did not affect the faecal dry matter content and total nitrogen level, yet it increased the ash content of the faeces. Consequently, it was demonstrated that the addition of up to $2 \% \mathrm{MZ}$ to lamb grower feed does not have a negative impact on performance and carcass yield of the animals, but affects serum total protein, calcium and phosphorus concentrations.
\end{abstract}

Keywords: Carcass, faecal ash, glucose, mineral, nitrogen

\# Corresponding author: nndede@agri.ankara.edu.tr

\section{Introduction}

Zeolites are mineral compounds, which because of their porous structure and high ion-exchange capacity can adsorb and absorb various gases, smells, water, humidity, petrochemical substances, low-level radioactive elements, toxic materials and heavy metals. Briefly, they can exchange their own cations for others (Melenova et al., 2003). Natural zeolites are utilized in a number of industries such as pollution control, vegetable production, energy, mining, construction, detergents and paper production (Kesraoui-Ouki et al., 1994; Mumpton, 1999). Furthermore, powder-form zeolites do not have chemical reactions with nutrients or bodily fluids since they are inert in the digestion system, similar to many silicates (Ivkovic et al., 2004), and thus can be used without ill effects in human and animal nutrition. Hecht (2010) showed positive effects of natural zeolites on detoxification of the body, the immune system, mineral metabolism, blood circulation, nervous system and digestion. As a result of increased consumer awareness in recent years, some countries have adopted good agricultural practices that are environmentally friendly, contribute significantly to human and animal health, do not allow the use of chemical and artificial fertilizers, and provide safe and healthy foods. For these reasons, researchers have sought safe and beneficial additives that carry no risk of leaving harmful residues in the course of vegetable and animal production. Zeolites fall in this class of additives.

Since zeolites possess the qualities of efficient absorption, ion exchange, dehydration-rehydration and catalyzation, for the past 30 - 35 years they have been investigated in relation to animal nutrition. The naturally occurring varieties of zeolite are safely utilized in organic animal production because of their outstanding qualities in adsorbing toxins, removing bad smells, enhancing performance and improving the quality of egg shells. Zeolites are used in animal feeds as a pellet binder, to improve ammonia utilization, to bind toxins and heavy metals, as a buffering agent, and to reduce bloat and other metabolic problems (Bechtel \& Hutchenson, 2003). Moreover, they are utilized for a wide range of purposes such as amelioration of the effects of mycotoxins, treatments of animal diarrhoea syndromes and milk fever, and reduction of 
skeletal deformities (Papaioannou et al., 2005). Although zeolites have such a wide spectrum of uses, they have not yet been fully integrated into the Turkish or global market since they do not meet the required criteria in terms of purity and pore diameter (Gülen et al., 2012). Today, zeolites are processed through micronization so that their particle size is reduced and their surface areas expanded. This final form is believed to have more efficient properties than zeolites in their natural and unprocessed forms. A study conducted with diabetic mice showed that $M Z$ caused a substantial reduction in lipid peroxidation and blood glucose levels (Zarkovic et al., 2003). The results of another study (Concepcion-Rosabal et al., 1997) showed that natural zeolites were very good glucose adsorbents, which might be beneficial in treating diabetes. Because of their ability to promote quick healing, zeolites are utilized widely in Cuba in curing the surface wounds of horses and other farm animals (Mumpton, 1999). Zeolites are also used as efficient absorbents of aflatoxins from the feeds (Rizzi et al., 2003). In a study to analyse the impact of zeolites on ammonia accumulation in the barn, it was recorded that when scattered on the ground and in paddocks they eliminated the intense smell of ammonia in the environment and improved the performance of the animals (Bozkurt, 2006). Results of in vivo and in vitro studies in the 1970s demonstrated that zeolites can adsorb up to $15 \%$ of the ammonia in the rumen and thus reduce ammonia toxicity in ruminants (White \& Ohlrogge, 1974). Galyean \& Chabot (1981), Hemken et al. (1984), Sweeney et al. (1984) and Erwanto et al. (2011) stated that the addition of zeolites to concentrate feeds could alter rumen fermentation. Zeolites release ammonia slowly owing to their selectivity during ion exchange, thereby reducing excessive ammonia accumulation in the rumen after feeding, and thus providing a more consistent rumen environment. This action impacts positively on rumen fermentation and on animal performance (Sweeney et al., 1984; Filya et al., 1999; Stojkovic et al., 2005; Ghaemnia et al., 2010; Kardaya et al., 2012). It has also been claimed that zeolites act as buffering agents when there is an increase in the acidity of the rumen (Peterson, 1980). In a study exploring this characteristic, $2.5 \%$ and $5.0 \%$ zeolites were added to fattening concentrate diets, and brought about lower pH levels after their inclusion (McCollum \& Galyean, 1983). In a study investigating the impact of zeolites on milk quality, an addition of $2.5 \%$ of clinoptilolite (zeolite) to goat feeds was demonstrated to improve milk fat and milk hygiene (Katsoulos et al., 2009). In addition to their positive impacts on animal performance, zeolites improve metabolism and may prevent from some metabolic diseases. Owing to the calcium absorption properties of clinoptilolites are utilized in the dry rations of dairy cows. It is reported that they might decrease the risk of hypocalcaemia (Thilsing-Hansen et al., 2002; Katsoulos et al., 2005). Moreover, zeolites added to feeds have been recorded to reduce the number of cases of diarrhoea and soft stools in calves (Kondo et al., 1969; Watanabe et al., 1971) and lambs (Stojkovic et al., 2005).

The present research was performed to identify the effects of natural zeolite, reduced in particle size through micronization $(90 \%<5 \mu \mathrm{m})$, on fattening performance, blood chemistry and some serum mineral concentrations, and on the faecal ash and nitrogen $(\mathrm{N})$ levels in fattening lambs.

\section{Material and Methods}

Twenty five four-month-old Merino $x$ lle de France crossbred male lambs were used in this study. The animals were fed a lamb grower diet that contained $1 \%, 2 \%$ or $3 \% \mathrm{MZ}$, but was otherwise additive-free. The zeolite was of natural origin, processed only through micronization. Feed ingredients and diet samples were analysed for dry matter (DM), ash, crude protein (CP), crude fibre (CF), and ether extract (EE) according to standard procedures (AOAC, 1990), and neutral detergent fibre (NDF) and acid detergent fibre (ADF), according to Van Soest et al. (1991). The chemical and microbiological analyses results of MZ are presented in Table 1, and the structures of the alfalfa hay and concentrate feed, as well as the nutrients, are given in Table 2. In addition to the ad libitum lamb grower concentrate, the lambs were fed $100 \mathrm{~g} /$ day of alfalfa hay to ensure a healthy rumen development.

A completely randomized design was used, and implemented with four groups, namely the control group, and the other three being fed the various amounts of MZ. The lambs were kept in individual ironframed pens with dimensions of $1.0 \times 1.4 \mathrm{~m}$. In this trial, there were seven lambs in the control group, and six in each of the three experimental groups. In the fourth week of the experiment, all the animals received injections against enterotoxaemia and internal and external parasites. The study was performed over a 60day period from June to August.

Live weights of the animals were monitored with weighing checks once every two weeks prior to morning feeding, and feed allocated and refused were recorded daily. In the sixth week of the trial, blood samples were taken from the vena jugularis from four animals in each group, two hours after feeding. The blood was immediately transferred from the syringe to vacutainer (BD) tubes containing sodium heparin as an anti-clotting agent for glucose analyses, and additive-free vacutainer (BD) tubes for the other metabolites. Forty five minutes after sampling, plasma and serum were separated by centrifugation at $3000 \times g$ for 30 minutes at $15{ }^{\circ} \mathrm{C}$. Total proteins, creatinine, blood urea nitrogen (BUN), triglyceride, calcium, phosphorus, 
sodium, potassium and chlorine concentrations were determined on the serum samples, while glucose concentration was measured on blood plasma. Determination of total proteins, BUN, creatinine, glucose, triglyceride, calcium and phosphorus was carried out with spectrophotometry, and the tests for sodium, potassium and chlorine were performed with the ISE (ion selective electrode) method, using commercial kits on the Roche Cobas-C501 auto analyser.

In the final week of the study, faecal samples were collected in faecal bags from three animals in each group, and the samples were analysed for DM and nitrogen (N) content (AOAC, 1990). At the end of the experimental period, two animals, with weights closest to the average live weight in each group, were slaughtered and their carcass weights and yields were recorded. The hot carcass weights were determined after skinning the animals and separating the main body from the internal organs, except for the head, skin, four legs, testicles and kidneys. The cold carcass weights were measured after cooling down the hot carcass in a cooler at $4^{\circ} \mathrm{C}$ for 18 hours. Carcass yields were calculated as a ratio (\%) of the hot carcass weights to the slaughter weights.

One-way analysis of variance (ANOVA) was used to evaluate the data acquired from the study, and the significant differences of research criteria among treatments were tested with Duncan's multiple range tests (Duncan, 1955). All analyses were conducted using SPSS for Windows (version 21.0, 2012).

Table 1 Chemical and microbiological analyses of micronized zeolite $(\mathrm{MZ})^{\star}$

\begin{tabular}{|c|c|}
\hline Parameters & Results \\
\hline \multicolumn{2}{|l|}{ Physical properties } \\
\hline Physical appearance & White to pale green powder \\
\hline Particles size & Min. $\% 90<5 \mu \mathrm{m}$ \\
\hline \multicolumn{2}{|l|}{ Chemical properties } \\
\hline $\mathrm{CaO}, \%$ & $2.5-6.0$ \\
\hline $\mathrm{MgO}, \%$ & $0.25-1.00$ \\
\hline $\mathrm{K}_{2} \mathrm{O}, \%$ & $0.5-2.0$ \\
\hline $\mathrm{Na}_{2} \mathrm{O}, \%$ & $0.5-2.0$ \\
\hline $\mathrm{Fe}_{2} \mathrm{O}_{3}, \%$ & $0.1-2.5$ \\
\hline $\mathrm{Pb}, \mathrm{mg} / \mathrm{kg}$ & $<10$ \\
\hline $\mathrm{Hg}, \mathrm{mg} / \mathrm{kg}$ & $<5$ \\
\hline $\mathrm{Cd}, \mathrm{mg} / \mathrm{kg}$ & $<2$ \\
\hline As, mg/kg & $<3$ \\
\hline $\mathrm{F}, \mathrm{mg} / \mathrm{kg}$ & $<10$ \\
\hline Loss on drying, \% & $\leq 10$ \\
\hline \multicolumn{2}{|l|}{ Microbiological properties } \\
\hline Total plate count, cfu/g & $<1000$ \\
\hline Total yeast \& mould, cfu/g & $<100$ \\
\hline E. coli & Negative \\
\hline Salmonella & Negative \\
\hline Staphylococcus & Negative \\
\hline
\end{tabular}

*MZ analysis was performed by the Mikro Mineral d.o.o., Hegedušićeva bb, 10000 Zagreb, Croatia.

\section{Results and Discussion}

Table 3 presents the average values of the performance responses obtained from the lambs at the end of the study. No differences were observed throughout the study in terms of daily live weight gain, feed consumption and feed conversion ratio $(P>0.05)$. Likewise, zeolite addition to the lamb diets (Ochodnicky et al., 1986) and feedlot steer diets (McCollum \& Galyean, 1983) was reported to have no impact on feed conversion ratio. Moreover, several studies stated that the addition of zeolite increases feed consumption (Sanders et al., 1997; Koknaroglu et al., 2006; Camara et al., 2012; Stojkovic et al., 2012) and improved feed 
conversion ratio (Nestorov, 1983; Nowar et al., 1993; Filya et al., 1999; Koknaroglu et al., 2006). In all studies (Sanders et al., 1997; Filya et al., 1999; Koknaroglu et al., 2006; Camara et al., 2012) in which urea was included, it resulted in a decline in feed consumption, and intake was restored with the addition of zeolite.

Table 2 Ingredients and chemical compositions of the experimental diets and alfalfa hay

\begin{tabular}{|c|c|c|c|c|c|}
\hline Ingredients & Control & Zeo1 & Zeo2 & Zeo3 & Alfalfa hay \\
\hline Barley & 49.0 & 47.0 & 43.0 & 40.0 & \\
\hline Wheat & 21.0 & 22.0 & 25.0 & 27.5 & \\
\hline Sunflower meal & 20.0 & 20.0 & 20.0 & 19.0 & \\
\hline Soybean meal & 7.0 & 7.0 & 7.0 & 7.5 & \\
\hline Limestone & 2.5 & 2.5 & 2.5 & 2.5 & \\
\hline Salt & 0.4 & 0.4 & 0.4 & 0.4 & \\
\hline Vit./min. premix ${ }^{1}$ & 0.1 & 0.1 & 0.1 & 0.1 & \\
\hline Micronized zeolite & 0.0 & 1.0 & 2.0 & 3.0 & \\
\hline Total & 100.0 & 100.0 & 100.0 & 100.0 & \\
\hline \multicolumn{6}{|l|}{ Nutrients (g/kg DM) } \\
\hline Dry matter & 883.2 & 882.1 & 884.1 & 880.7 & 910.0 \\
\hline $\mathrm{ME}, \mathrm{MJ} / \mathrm{kg} \mathrm{DM}$ & 12.02 & 12.06 & 11.98 & 12.14 & 9.20 \\
\hline Crude protein & 188.0 & 187.5 & 189.6 & 191.7 & 134.2 \\
\hline Crude fibre & 93.5 & 91.7 & 91.4 & 88.6 & 327.0 \\
\hline Ether extract & 19.47 & 19.27 & 18.89 & 18.74 & 12.09 \\
\hline Ash & 59.4 & 62.8 & 60.7 & 70.1 & 87.9 \\
\hline NDF & 232.3 & 229.9 & 225.5 & 223.2 & 528.6 \\
\hline ADF & 116.6 & 115.8 & 113.7 & 112.3 & 401.1 \\
\hline
\end{tabular}

Zeo1, Zeo2, Zeo 3, treatments were basal diet (control) supplemented with micronized zeolite at the level of $1 \%$, $2 \%$, or $3 \%$, respectively. NDF: neutral detergent fibre; ADF: acid detergent fibre.

${ }^{1}$ Supplied per kg of diet $12500000 \mathrm{IU}$ vitamin $\mathrm{A} ; 3000000 \mathrm{IU}$ vitamin $\mathrm{D}_{3} ; 25000 \mathrm{mg}$ vitamin E; $1960 \mathrm{mg}$ vitamin $\mathrm{K}_{3} ; 1974$ $\mathrm{mg}$ vitamin $\mathrm{B}_{1} ; 6000 \mathrm{mg}$ vitamin $\mathrm{B}_{2} ; 2475 \mathrm{mg}$ vitamin $\mathrm{B}_{6}$ : $20 \mathrm{mg}$ vitamin $\mathrm{B}_{12}$ : $50049 \mathrm{mg}$ niacin; $10001 \mathrm{mg}$ calcium $\mathrm{D}$ pantothenate; $952 \mathrm{mg}$ folic acid; $200 \mathrm{mg} \mathrm{D}$-biotin; $64000 \mathrm{mg}$ manganese; $33000 \mathrm{mg}$ iron; 60000 mg zinc; $15000 \mathrm{mg}$ copper; $400 \mathrm{mg}$ iodine; 300 mg cobalt; $500 \mathrm{mg}$ selenium; 1000 mg butylated hydroxytoluene (BHT).

There were significant differences in terms of slaughter weight, with the highest weights in the control group and in the groups receiving the diets containing $1 \%$ and $2 \% \mathrm{MZ}$, and the lowest weights in the group fed the $3 \% \mathrm{MZ}$ diet $(P<0.05)$. These results indicate that the addition of $\mathrm{MZ}$ up to $2 \%$ did not affect the carcass weight of lambs, while beyond this level, negative impacts were observed. Studies by Kondo \& Wagai (1968), Kondo et al. (1969), Cool \& Willard (1982), Pond (1984), Filya et al. (1999) and Stojkovic et al. (2005; 2012) stated that the addition of zeolite to the ration improved animal growth. Many studies reported similar findings to the current research, zeolite demonstrating no negative effect on growth (Theilemans \& Bodart, 1982; McCollum \& Galyean, 1983; Sweeney et al., 1984; Mumpton, 1985; Çolpan et al., 1986; Ochodnicky et al., 1986; Sanders et al., 1997; Tabbaa, 1999; Sherwood et al., 2005; Koknaroglu et al., 2006).

As seen in Table 3, the lowest slaughter weight was $30.7 \mathrm{~kg}$ in the group fed the $3 \% \mathrm{MZ}$ treatment diet $(P<0.05)$. The hot and cold carcass weights $(\mathrm{kg})$ were found to be higher in the control group and in the groups with $1 \%$ and $2 \% \mathrm{MZ}$ added to the concentrate feeds compared with the group with $3 \% \mathrm{MZ}(P<0.01)$. Similarly, Sadeghi \& Shawrang (2006) found that hot carcass weights decreased when natural zeolite was added to the diet of steers. Contrary to the findings of the current study, some studies showed that the addition of zeolite did not affect carcass weight or carcass components (McCollum \& Galyean, 1983; Pond, 1984; Sanders et al., 1997; Sherwood et al., 2005), but reduced carcass yield (Sanders et al., 1997). In this study, no significant differences were observed in terms of carcass yield across the experimental groups. 
Table 3 Effect of supplemental micronized zeolite on growth performance of lambs

\begin{tabular}{lcccccc}
\hline \multirow{2}{*}{ Criteria } & \multicolumn{2}{c}{ Control } & \multicolumn{2}{c}{ Zeolite, \% } & \multicolumn{2}{c}{$\boldsymbol{P}$-value } \\
\cline { 2 - 7 } & $\mathbf{0 . 0}$ & $\mathbf{1 . 0}$ & $\mathbf{2 . 0}$ & $\mathbf{3 . 0}$ & Linear & Quadratic \\
\hline Initial body weight (kg) & $19.6 \pm 1.21$ & $22.8 \pm 0.09$ & $21.7 \pm 1.68$ & $20.2 \pm 2.31$ & 0.837 & 0.345 \\
Average daily gain (g) & $321.8 \pm 9.64$ & $329.4 \pm 23.90$ & $306.3 \pm 23.38$ & $244.3 \pm 25.70$ & 0.111 & 0.323 \\
Feed intake (g/d) & $1329 \pm 74.7$ & $1335 \pm 116.0$ & $1338 \pm 70.8$ & $1145 \pm 50.4$ & 0.167 & 0.203 \\
Feed conversion ratio & $4.24 \pm 0.258$ & $4.57 \pm 0.212$ & $4.65 \pm 0.448$ & $4.60 \pm 0.301$ & 0.412 & 0.454 \\
Slaughter weight (kg) & $37.5 \pm 0.05^{\mathrm{a}}$ & $37.9 \pm 0.10^{\mathrm{a}}$ & $36.2 \pm 1.75^{\mathrm{a}}$ & $30.7 \pm 1.25^{\mathrm{b}}$ & 0.017 & 0.028 \\
Hot carcass weight (kg) & $17.2 \pm 0.20^{\mathrm{a}}$ & $17.6 \pm 0.00^{\mathrm{a}}$ & $17.1 \pm 0.30^{\mathrm{a}}$ & $14.3 \pm 0.10^{\mathrm{b}}$ & 0.024 & 0.001 \\
Cold carcass weight (kg) & $16.8 \pm 0.20^{\mathrm{a}}$ & $17.2 \pm 0.00^{\mathrm{a}}$ & $16.7 \pm 0.30^{\mathrm{a}}$ & $14.1 \pm 0.10^{\mathrm{b}}$ & 0.024 & 0.001 \\
Carcass yield (\%) & $45.9 \pm 0.60$ & $46.4 \pm 0.12$ & $47.4 \pm 1.46$ & $46.8 \pm 2.23$ & 0.536 & 0.664 \\
& & & & & & \\
\hline
\end{tabular}

$\overline{\mathrm{a}, \mathrm{b}}$ Means within a row with different letters differ significantly $(P<0.05)$.

Table 4 presents the averages for the biochemical properties that were analysed in the blood samples collected from the lambs. The results reveal no differences in the concentrations of BUN, creatinine, glucose, triglyceride, sodium, potassium and chlorine. However, there were differences in terms of total serum protein $(P<0.05)$, serum calcium and phosphorus concentrations $(P<0.05)$. Supplementation of $3 \% \mathrm{MZ}$ in the lamb grower diet showed a linearly increase in total serum protein level $(P=0.038)$. The data suggest that $\mathrm{MZ}$ alters protein metabolism. Serum concentrations of phosphorus were significantly lower $(P=0.025)$ in the blood samples from lambs fed diets supplemented with $2 \% \mathrm{MZ}$. Grabherr et al. (2009) reported that zeolite as a calcium binder in the dry period of dairy cows is a new strategy in preventing parturient hypocalcaemia in dairy cows. In the present study, the lowest serum calcium levels were observed in the $2 \%$ and $3 \% \mathrm{MZ}$ supplementation groups $(P=0.021)$.

Table 4 Effect of supplemental micronized zeolite on some blood parameters of lambs

\begin{tabular}{|c|c|c|c|c|c|c|}
\hline \multirow{2}{*}{ Parameters } & \multirow{2}{*}{$\begin{array}{c}\text { Control } \\
0.0\end{array}$} & \multicolumn{3}{|c|}{ Zeolite, \% } & \multicolumn{2}{|c|}{$P$-value } \\
\hline & & 1.0 & 2.0 & 3.0 & Linear & Quadratic \\
\hline Total protein (g/dL) & $6.60 \pm 0.091^{\mathrm{ab}}$ & $6.45 \pm 0.185^{b}$ & $6.98 \pm 0.243^{\mathrm{ab}}$ & $7.08 \pm 0.206^{\mathrm{a}}$ & 0.038 & 0.532 \\
\hline BUN (mg/dL) & $21.90 \pm 1.163$ & $19.60 \pm 1.858$ & $25.28 \pm 0.686$ & $20.38 \pm 2.497$ & 0.952 & 0.409 \\
\hline Creatinine (mg/dL) & $0.61 \pm 0.041$ & $0.58 \pm 0.048$ & $0.61 \pm 0.029$ & $0.53 \pm 0.042$ & 0.221 & 0.487 \\
\hline Glucose (mg/dL) & $88.3 \pm 1.38$ & $85.8 \pm 3.01$ & $83.5 \pm 1.94$ & $87.5 \pm 4.74$ & 0.740 & 0.291 \\
\hline Triglyceride (mg/dL) & $29.50 \pm 5.454$ & $32.25 \pm 2.869$ & $25.00 \pm 3.240$ & $32.25 \pm 1.031$ & 0.952 & 0.554 \\
\hline $\mathrm{Na}(\mathrm{mEq} / \mathrm{L})$ & $148.5 \pm 0.65$ & $149.5 \pm 1.19$ & $147.8 \pm 0.85$ & $149.0 \pm 0.41$ & 0.948 & 0.888 \\
\hline $\mathrm{K}(\mathrm{mEq} / \mathrm{L})$ & $4.98 \pm 0.057$ & $5.13 \pm 0.225$ & $4.94 \pm 0.138$ & $5.39 \pm 0.165$ & 0.170 & 0.364 \\
\hline $\mathrm{Cl}(\mathrm{mEq} / \mathrm{L})$ & $103.8 \pm 0.75$ & $103.0 \pm 1.00$ & $103.5 \pm 0.957$ & $102.8 \pm 0.95$ & 0.528 & 1.00 \\
\hline $\mathrm{Ca}(\mathrm{mg} / \mathrm{dL})$ & $11.05 \pm 0.132^{b}$ & $11.03 \pm 0.149^{b}$ & $10.50 \pm 0.248^{\mathrm{a}}$ & $10.38 \pm 0.328^{a}$ & 0.021 & 0.829 \\
\hline$P(m g / d L)$ & $9.13 \pm 0.350^{\mathrm{a}}$ & $9.13 \pm 0.239^{\mathrm{a}}$ & $7.85 \pm 0.126^{b}$ & $9.67 \pm 0.214^{\mathrm{a}}$ & 0.849 & 0.025 \\
\hline
\end{tabular}

BUN: blood urea nitrogen; Na: sodium; K: potassium; Cl: chlorine; Ca: calcium; P: phosphorus.

${ }^{a, b}$ Means within a row with different superscripts differ significantly $(P<0.05)$.

While some studies stated that the addition of MZ substantially increases urea (Sadeghi \& Shawrang, 2006) and ammonium nitrogen concentrations in blood (Clara \& Gennard, 1968; Çolpan et al., 1986; Filya et al., 1999), others are consistent with the current findings, emphasizing that the addition of zeolite does not affect urea and ammonium nitrogen levels (Pond, 1984; Kardaya et al., 2012), and non-reduced plasma urea concentration (Ghaemnia et al., 2010). Ghaemnia et al. (2010) performed a study with five-month-old lambs, 
and revealed that the plasma glucose concentration was not affected by the addition of zeolite, but tended to decline. In the present study, plasma glucose concentration was not affected by treatment. In this study, serum calcium and phosphorus levels were affected by the MZ supplementation $(P<0.05)$. Thilsing-Hansen et al. (2003) stated that zeolite given to dairy cows during the pre-partum period increased serum calcium concentration and reduced phosphorus concentration. However, the phosphorus level returned to normal one week after parturition. In the current study performed on lambs, an addition of $2 \% \mathrm{MZ}$ reduced the serum phosphorus level, but remained at the higher level with the $3 \% \mathrm{MZ}$ addition (Table 4). When compared in terms of serum calcium level, Pond (1984) stated that zeolite supplementation to lamb diets had no impact on serum calcium level. In another study, Sweeney et al. (1980) demonstrated that the use of zeolite $(50 \mathrm{~g} / \mathrm{kg})$ in concentrate feeds of steers reduced blood potassium concentration. In terms of blood biochemical criteria, the differences in the results of various studies are attributed to the species and to the physiological periods of the animals, as well as the blood collection time (prior to or following feeding, etc.), structure of the feed mixtures used for feeding the animals (use of urea, etc.) and the duration of the study.

Table 5 Effects of supplemental micronized zeolite on dry matter, ash and nitrogen concentration (\%) in the faeces of the lambs

\begin{tabular}{lcccccc}
\hline \multirow{2}{*}{ Criteria } & Control & \multicolumn{3}{c}{ Zeolite, $\%$} & \multicolumn{2}{c}{$\boldsymbol{P}$-value } \\
\cline { 2 - 7 } & $\mathbf{0 . 0}$ & $\mathbf{1 . 0}$ & $\mathbf{2 . 0}$ & $\mathbf{3 . 0}$ & Linear & Quadratic \\
\hline \multirow{2}{*}{ Dry matter } & $35.9 \pm 2.02$ & $33.8 \pm 3.20$ & $37.0 \pm 2.74$ & $35.8 \pm 2.75$ & 0.811 & 0.866 \\
Ash & $14.11 \pm 0.262^{\mathrm{b}}$ & $18.30 \pm 0.459^{\mathrm{a}}$ & $17.64 \pm 0.812^{\mathrm{a}}$ & $18.05 \pm 0.810^{\mathrm{a}}$ & 0.013 & 0.041 \\
Nitrogen & $0.82 \pm 0.067$ & $0.81 \pm 0.132$ & $0.83 \pm 0.079$ & $0.88 \pm 0.028$ & 0.407 & 0.647 \\
\hline
\end{tabular}

${ }^{a, b}$ Means within a row with different letters differ significantly $(P<0.05)$.

Table 5 presents the results from faeces collected from the animals at the end of the trial. It shows no differences between the control and trial groups in terms of $D M$ and total $\mathrm{N}$ ratio, whereas the faecal ash ratio increased in relation to the quantity of $M Z$ in the diet $(P<0.01)$. Similar findings were reported by Sherwood et al. (2005) in a study performed on cattle, which showed that zeolite addition did not alter manure DM and N content. In other research conducted by Bechtel \& Hutchenson (2003), adding zeolite at $1.2 \%$ did not affect faecal $\mathrm{N}$ level for the first 10 - 15 days. However, from 15 to 30 days, dietary zeolite excreted in the faeces bound ammonia, thus reducing $\mathrm{N}$ losses. In this study, an increase was observed in the faecal ash ratio in relation to the addition of MZ. However, this increase was not affected by the ratio of $\mathrm{MZ}$ added. No mineral analysis was performed on the faeces in this study. It is believed that identifying the impacts of $\mathrm{MZ}$ addition on mineral excretion through mineral analyses would be beneficial in future studies.

\section{Conclusions}

The study demonstrated that the addition of MZ up to $2 \%$ of the grower feed for weaned lambs did not create negative or positive effects on the animals' performance and carcass ratio. The addition of zeolite did not seem to be beneficial to fattening performance of crossbred male lambs. However, more detailed studies aimed at clarifying the impact of MZ, especially on blood total protein, calcium and phosphorus metabolism, should be beneficial in relation to animal and human health.

\section{Authors' Contributions}

NNT: Data collection, performed chemically analysis on all feed samples, feed formulation, data analysis and interpreted data, wrote manuscript, revision of the article and acted as corresponding author. AY: Design the study, supervised development of work, helped in data interpretation and manuscript evaluation. EÖ: Helped to design the study and feed formulation, appropriate animal selection and helped to data collection. OY: Blood sampling, animals' health control and injections (enterotoxaemia and internal/external parasites). FC: Data collection, helped to evaluate and edit the manuscript. All authors commented on initial and final versions of the article.

\section{Conflict of Interest Declaration}

The authors declare that they have no conflict of interest. 


\section{References}

AOAC, 1990. Official Methods of Analysis (15th ed.). Association of Official Analytical Chemists, Inc., Arlington, Virginia, USA.

Bechtel, R. \& Hutchenson, D., 2003. Adding CZ to rations may reduce nitrogen losses. Feedstuffs 7, 75.

Bozkurt, Y., 2006. The use of zeolite to improve housed beef cattle performance by reducing ammonia accumulation in small farm conditions. Asian J. Anim. Vet. Adv. 1, 60-64.

Camara, L.R.A., Valadares, Filho, S.C., Leao, M.I., Valadares, R.F.D., Dias, M., Gomide, A.P.C., Barros, A.C.W., Nascimento, V.A., Ferreira, D.J., Fae, J.T., Carneiro, C. \& Cardoso, L.L., 2012. Zeolite in the diet of beef cattle. Arq. Bras. Med. Vet. Zoo. 64, 631-639.

Clara, R. \& Gennard, M., 1968. Dietary factors affecting utilization of urea nitrogen by sheep in purified diets. J. Anim. Sci. 95, 122-128.

Çolpan, İ., Yalçın, S., Çetin, O. \& Gündoğdu, N., 1986. Farklı düzeylerde zeolit içeren rasyonların Merinos kuzularında besi performansı karkas özellikleri ile bazı kan ve rumen sıvısı metabolitleri üzerine etkisi. Doğa Vet. ve Hay. Derg. D1, 10 (1). (in Turkish).

Concepcion-Rosabal, B., Rodriguez-Fuentes, G. \& Simon-Carballo, R., 1997. Development and featuring of the zeolitic active principle fz: glucose adsorbent zeolites. Zeolites 19, 47-50.

Cool, W.M. \& Willard, J.M., 1982. Effect of clinoptilolite on swine nutrition. Nutr. Rep. Int. 26, 759.

Duncan, D.B., 1955. Multiple Range and Multiple F tests. Biometrics 11, 1-42.

Erwanto, I.R., Zakaria, W.A. \& Prayuwidayati, M., 2011. The use of ammoniated zeolite to improve rumen metabolism in ruminant. Anim. Prod. 13 (3), 138-142.

Filya, İ., Karabulut, A., Ak, İ. \& Akgündüz, V., 1999. Entansif kuzu besisinde zeolit kullanılmasının kuzuların besi performansı ile bazı kan ve rumen sıvısı metabolitleri üzerine etkileri. J. Anim. Prod. 40, 39-48. (in Turkish).

Galyean, M.L. \& Chabot, R.C., 1981. Effects of sodium bentonite, buffer salts, cement kiln dust and clinoptilolite on rumen characteristics of beef steers fed a roughage diet. J. Anim. Sci. 52, 1197-1204.

Ghaemnia, L., Bojarpour, M., Mirzadeh, Kh., Chaji, M. \& Eslami, M., 2010. Effects of different levels of zeolite on digestibility and some blood parameters in Arabic lambs. J. Anim. Vet. Adv. 9, 779-781.

Grabherr, H., Spolders, M., Lebzien, P., Hüther, L., Flachowsky, G., Fürll, M. \& Grün, M., 2009. Effect of zeolite A on rumen fermentation and phosphorus metabolism in dairy cows. Arch. Anim. Nutr. 63 (4), 321-336.

Gülen, J., Zorbay, F. \& Arslan, S., 2012. Zeolitler ve kullanım alanları. Karaelmas Sci. Eng. J. 2, $63-68$ (in Turkish).

Hecht, K., 2010. Clinoptilolite-zeolite and montmorillonite minerals rich in $\mathrm{SiO}_{2}$ : What are they? What can they achieve? Why are they so important for human health? Application of natural zeolites in medicine and cosmetology ZEOMEDCOS. SWB, Baku-London. pp. 7-45.

Hemken, R.W., Harmon, R.J. \& Mann, L.M., 1984. Effect of clinoptilolite on lactating dairy cows fed a diet containing urea as a source of protein. In: Zeo-Agriculture: Use of natural zeolites in agriculture and aquaculture. Eds: Pond, W.G. \& Mumpton, F.A., Westview Press, Boulder, CO. pp. 171.

Ivkovic, S., Deutsch, U., Silberbach, A., Walraph, E. \& Mannel, M., 2004. Dietary supplementation with the tribomechanically activated zeolite clinoptilolite in immunodeficiency: effects on the immune system. Adv. Ther. 21, 135-47.

Kardaya, D., Sudrajat, D. \& Dihansih, E., 2012. Efficacy of dietary urea-impregnated zeolite in improving rumen fermentation characteristics of local lamb. Media Peternakan. 35, 207-213.

Katsoulos, P.D., Roubies, N., Panousis, N., Arsenos, G., Christaki, E. \& Karatzias, H., 2005. Effects of long-term dietary supplementation with clinoptilolite on incidence of parturient paresis and serum concentrations of total $\mathrm{Ca}, \mathrm{P}$, magnesium, potassium and sodium in dairy cows. Am. J. Vet. Res. 66, 2081-2085.

Katsoulos, P.D., Zarogiannis, S., Roubies, N. \& Christodoulopoulos, G., 2009. Effect of long-term dietary supplementation with clinoptilolite on performance and selected serum biochemical values in dairy goats. Am. J. Vet. Res. 70, 346-52.

Kesraoui-Ouki, S., Cheeseman, C.R. \& Perry, R., 1994. Natural zeolite utilisation in pollution control: A review of applications to metals' effluents. J. Chem. Technol. Biotechnol. 59, 121-126.

Koknaroglu, H., Toker, M.T. \& Bozkurt, Y., 2006. Effect of zeolite and initial weight on feedlot performance of Brown Swiss cattle. Asian J. Anim. Vet. Adv. 1, 49-54.

Kondo, N. \& Wagai, B., 1968. Experimental use of clinoptilolite-tuff as dietary supplements for pigs. Yotonkai, May 1-4.

Kondo, K., Fujishiro, S., Suzuki, F., Taga, T., Morinaga, H., Wagai, B. \& Kondo, T., 1969. Effect of zeolites on calf growth. Chikisun No Kenikyu 23, 987-988.

McCollum, F.T. \& Galyean, M.L., 1983. Effect of clinoptilolite on rumen fermentation, digestion and feedlot performance in beef steers fed high concentrate diets. J. Anim. Sci. 56, 517-524.

Melenova, L., Ciahotny, K., Jirglova, H., Kusa, H. \& Ruzek, P., 2003. Removal of ammonia from waste gas by means of adsorption on zeolites and their subsequent use in agriculture. Chem. Listy 97, 562-568.

Mumpton, F.A., 1985. Using zeolites in agriculture. https://www. princeton.edu/ ota/disk2/1985/8512/851210.pdf. Accessed: 20.08.2014.

Mumpton, F.A., 1999. La roca magica: Uses of natural zeolites in agriculture and industry. Proc. Natl. Acad. Sci. USA, 96, 3463-3470.

Mumpton, F.A. \& Fishman, P.H., 1977. The application of natural zeolites in animal science and aquaculture. J. Anim. Sci. 45, 1188-1203.

Nestorov, N., 1983. Possible applications of natural zeolites in animal husbandry. In: Zeo-agriculture: Use of natural zeolites in agriculture and aquaculture. Eds: Pond, W.G. \& Mumpton, F.A., Westview Press, Boulder, Colorado, USA. pp. 163-169. 
Nowar, M.S., Al-Shawabkeh, K. \& Khoury, H.N., 1993. Effect of feeding farm animals with Jordanian clay deposits containing montmorillonite: 1 . Effect on fattening lambs performance, with special reference to blood hematology, liver and kidney functions, and parasitological and serological examinations. Zagaz 1. Agric. Res. 20 (2A), 651-667.

Ochodnicky, D., Huncik, M. \& Bajdal, K., 1986. The effect of zeolite supplement at lamb fattening. Scientific Works of the Research Institute for Sheep Breeding in Trencin, XIII, 161-171.

Papaioannou, D., Katsoulos, P.D., Panousis, N. \& Karatzias, H., 2005. The role of natural and synthetic zeolites as feed additives on the prevention and/or the treatment of certain farm animal diseases. A review. Microporous Mesoporous Mater. 84, 161-170.

Peterson, S., 1980. Observations from the literature concerning the use of natural mineral zeolite clinoptilolite as an additive to animal feed. Leonard Resources, Inc., Albuquerque, N.M., USA.

Pond, W.G., 1984. Added to corn, corn-fish meal and corn-soybean meal diets response of growing lambs to clinoptilolite or zeolite NaA. J. Anim. Sci. 59, 1320-1328.

Rizzi, L., Simioli, M., Roncada, P. \& Zaghini, A., 2003. Aflatoxin B1 and clinoptilolite in feed for laying hens: effects on egg quality, mycotoxin residues in livers, and hepatic mixed-function oxygenase activities. J. Food Prot. 66, 860-865.

Sadeghi, A.A. \& Shawrang, P., 2006. The effect of natural zeolite on nutrient digestibility, carcass traits and performance of Holstein steers given a diet containing urea. Anim. Sci. 82, 163-167.

Sanders, K.J., Richardson, C.R. \& Harper, S., 1997. Effects of zeolites on performance of feedlot cattle. Texas Technical University Animal Science, UK. http://www.zeolite-products.com/ktml2/files/uploads/ Effects\%20of\%20zeolites\%20on\%20performance\%20of\%20feedlot\%20cattle.pdf

Stojkovic, J., Adamovic, M., Lemic, J. \& Jasovic, B., 2005. The effect of natural zeolite on fattening lambs production results. Biotech. Anim. Husb. 21, 49-52.

Stojkovic, J., llic, Z., Ciric, S., Ristanovic, B., Petrovic, M.P., Caro Petrovic, V. \& Kurcubic, V., 2012. Efficiency of zeolite basis preparation in fattening lambs diet. Biotech. Anim. Husb. 28, 545-552.

Sherwood, D.M., Erickson, G.E. \& Klopfenstein, T.J., 2005. Effect of clinoptilolite zeolite on cattle performance and nitrogen volatilization loss. Nebraska Beef Cattle Reports. pp. 177. http://digitalcommons.unl.edu/animalscinbcr/177.

Sweeney, T.F., Bull, L.S. \& Hemken, R.W., 1980. Effect of zeolite as a feed additive on growth performance in ruminants. J. Anim. Sci. 51, 401-409.

Sweeney, T.F., Cervantes, A., Bull, L.S. \& Hemken, R.W., 1984. Effect of dietary clinoptilolite on digestion and rumen fermentation in steers. In: Zeo-Agriculture: Use of Natural Zeolites in Agriculture and Aquaculture. Eds: Pond, W.G. \& Mumpton, F.A., Westview Press, Boulder, CO. pp. 177-187.

Tabbaa, M.J., 1999. Effect of breed and sex on performance of lambs fed two levels of clay minerals in the fattening rations. Agr. Sci. 26, 377-386.

Theilemans, M.F. \& Bodart, C., 1982. Zeolite in the feeding of growing-finishing pigs. 1. Effect on performance. Rev. AgrBrussels. 35, 2799-2805.

Thilsing-Hansen, T., Jorgensen, R.J., Enemark, J.M.D. \& Larsen, T., 2002. The effect of zeolite a supplementation in the dry period on periparturient calcium, phosphorus, and magnesium homeostasis. J. Dairy Sci. 85, 1855-1862.

Thilsing-Hansen, T., Jorgensen, R.J., Enemark, J.M., Zelvyte, R. \& Sederevicius, A., 2003. The effect of zeolite A supplementation in the dry period on blood mineral status around calving. Acta Vet. Scand. 97, 87-95.

Van Soest, P.J., Robertson, J.B. \& Lewis, B.A., 1991. Methods for dietary fiber, neutral detergent fiber, and nonstarch polysaccharides in relation to animal nutrition. J. Dairy Sci. 74, 3583-3597.

Watanabe, S., Yanaka, Y. \& Juroda, A., 1971. Report on the experimental use of zeolite tuff as a dietary supplement for cattle Rep. Okoyama Prefecture Fed. Agr. Coop. Ass. April, pp. 18.

White, J.L. \& Ohlrogge, A.J., 1974. Ion exchange materials to increase consumption of non-protein nitrogen in ruminants. Can. Patent 939186. pp. 30.

Zarkovic, N., Zarkovic, K., Kralj, M., Borovic, S., Sabolovic, S., Blazi, M.P., Cipak, A. \& Pavelic, K., 2003. Anticancer and antioxidative effects of micronized zeolite clinoptilolite. Anticancer Res. 2B, 1589-95. Ruder Boskovic Institute, Division of Molecular Medicine, Bijenicka 54, HR-10000 Zagreb, Croatia. 